\title{
THE INFLUENCE OF LIQUIDITY, PROFITABILITY, AND SOLVENCY ON BANKING STOCK PRICE LISTED ON IDX FOR THE 2015-2019 PERIOD
}

\author{
Kiran Raj ${ }^{1}$, Narti Eka Putri ${ }^{2}$ \\ Universitas Tanri Abeng \\ e-mail: kiran.raj@tau.ac.id'1 ${ }^{1}$ narti.putri@tau.ac.id ${ }^{2}$ \\ Received: September $7^{\text {th }} 2021$ \\ Approved: October $25^{\text {th }} 2021$
}

\begin{abstract}
This quantitative research aims to determine the effect of liquidity, profitability and solvency on stock prices. The type of data used is secondary data obtained from the Indonesia Stock Exchange website and the Yahoo Finance website. A total of 38 banking companies listed on the IDX from 2015-2019 were sampled based on purposive sampling and processed using SPSS version 23 software. The variables used in the research were liquidity, profitability and solvency as well as stock prices. The partial results of this study indicate that liquidity and solvency have a significant effect on stock prices while solvency has no significant effect on stock prices. And the results together also show that liquidity, profitability, and solvency have a significant effect on stock prices.
\end{abstract}

Keywords: Liquidity, Profitability, Solvency, Stock Price

\section{Intoduction}

Business actors who want to maintain their business need to do better business management. The banking sector is no exception. Law Number 7 of 1998 concerning banking 


\section{Journal of Management and Leadership}

Vol.4 No.1, May 2021

states that a bank is a business entity that collects public funds in the form of savings and distributes them to the public in the form of credit and or other forms in order to improve the standard of living of many people. Through this intermediation function, banks are highly relied upon to contribute to creating stability in the financial system. According to Octaviani and Komalasarai (2017), one of the benefits of banking in life is as an investment model. Although the Bank is often a place to borrow money, the Bank also needs to develop its business. Managing and developing its business, the Bank needs funds or capital to run business operations. Therefore, Banks need to look for alternatives, namely by borrowing from external parties, adding customers in credit or being able to sell securities on the capital market or stock exchange.

According to Anwar (2019), in the basic principles of corporate financial management, the capital market is a market that trades long-term financial instruments. Some of the financial instruments traded include: stocks (stocks), bonds (bonds) and others. According to Mardian and Sanusi (2017), capital market products such as stocks are one of the main choices in addition to other securities. The Indonesian capital market has become the attention of many parties, especially the business community. The capital market is a very effective medium to be able to channel and invest funds that have a productive and profitable impact on investors. According to Hermuningsih (2012: 80) in the journal Adipalguna and Suarjaya (2016), in general the purpose of stock investment is to get capital gains and dividends. According to Adipalguna and Suarjaya (2016), Capital gain is the difference between the purchase price and the selling price of shares, while dividends are part of the company's profits distributed to shareholders. Meanwhile, through capital market activities, companies can obtain funds to finance operational activities and company expansion.

Before investing, investors need to look at the information provided by the company. Information obtained from companies is usually based on the company's performance as reflected in the financial statements. In accordance with the Financial Accounting Standards (SAK) revised on July 1, 2009, it is obligatory for every company (especially public companies) to present financial reports, both interim or quarter (unaudited) financial reports and annual or annual (audited) financial reports. The annual financial report (which has been audited) is published by the Indonesian Capital Market Directory (ICMD) which includes a balance sheet 


\section{Journal of Management and Leadership}

Vol.4 No.1, May 2021

and income statement, as well as notes related to these financial statements. According to Hartono and Harjito (2014: 51) in the journal Aviliankara and Sarumpaet (2017), financial statements are an overview of the financial condition of a company in certain circumstances. Information from financial statements can be used as an illustration of a company's performance. Financial statements need to be analyzed, namely the process of evaluating economic prospects and company risks including analysis of the company's business environment, strategy, and financial position and financial performance. Financial statement analysis using financial ratios. Understanding financial ratios according to Sofyan Syarif Harahap (2002) in the journal Erwanda and Ruzikna (2017), explains that financial ratios are numbers obtained from the comparison of one financial statement post with other posts that have a relevant and significant relationship. Based on the financial statements, investors know the resulting level of Liquidity, Profitability, and Solvency.

The stock price according to David and Kurniawan (2010:3) in the journal Aviliankara and Sarumpaet (2017), reflects everything that is known about the stock and the stock price is the most efficient price. The stock price used in conducting transactions in the capital market is the price formed by the market mechanism, namely market supply and demand. The stock price of a company can describe the state or achievements of the company. Investors will be more attracted to companies that are judged to have a good reputation and achievement which can be seen from the company's financial statements (issuers). Issuers are obliged to publish financial statements for a certain period. This financial report is very useful for investors to assist in making investment decisions, such as selling, buying, or investing shares.

Problems in using accounting information to analyze liquidity ratios, profitability ratios, and solvency ratios in companies have been widely carried out because they are still considered interesting problems to study because of the inconsistency of the results of previous research (research gaps). As research conducted by Alfrida Rianisari, et al., (2018), Ni Made Putri Sri Rahayu and I Made Dana (2016), stated that liquidity had a significant positive effect on the company's stock price. The opposite result was obtained in research conducted by Halimatussakdiah (2018), which stated that liquidity had a significant negative effect on stock prices. Different results were found in research conducted by Machfiroh (2020), Octaviani and Komalasarai (2017), Adipalguna and Suarjaya (2016), Susilawati (2012) and Aviliankara and 


\section{Journal of Management and Leadership}

Vol.4 No.1, May 2021

Sarumpaet (2017) which stated that liquidity had no significant effect on stock prices. There is also research conducted by Sandra et al (2016), Rianisari (2018), Susilawati (2012) and Aviliankara and Sarumpaet (2017), stating that profitability has a significant positive effect on stock prices. On the other hand, research conducted by Alfianti A. and Andarini (2017), which states that profitability has a significant negative effect on stock prices. Different results were obtained in research conducted by Tiya et al (2018), Adipalguna and Suarjaya (2016), and Machfiro et al (2020), profitability has no significant effect on stock prices. And also research conducted by Ramadhani (2017), Ramdhani (2013), Susilawati (2012), states that solvency has a significant negative effect on stock prices. The opposite results were obtained by Faleni and Herdianto (2019), Sandra et al (2016), which stated that solvency had a significant positive effect on stock prices. Different results were found in research conducted by Adipalguna and Suarjaya (2016), Octaviani and Komalasarai (2017), and Machfiroh et al (2020), Aviliankara and Sarumpaet (2017), which stated that solvency had no significant effect on stock prices.

Based on the background above, the problems to be studied are as follows:

1. Does the company's liquidity ratio have a significant influence on the stock price?

2. Does the company's profitability ratio have a significant influence on the stock price?

3. Does the company's profitability ratio have a significant influence on the stock price?

4. Do the liquidity ratios, profitability ratios and solvency ratios of the company together have a significant influence on stock prices?

\section{Literature Review}

\section{Financial Statements}

Financial statements are very important accounting products and can also be used to make economic decisions that are useful for internal and external parties. According to Harahap (2006:105) financial statements are reports that describe the financial condition and results of operations of a company at a certain time or a certain period of time. According to Hartono and Harjito (2014: 51) financial statements are an overview of the financial condition of a company in certain circumstances. This information can be used as a description of the performance of a company. Meanwhile, according to Munawir (2010: 5), financial statements are a form of reporting consisting of a balance sheet and income statement as well as a report on changes in 
Journal of Management and Leadership

Vol.4 No.1, May 2021

equity. The balance sheet shows or describes the total assets, liabilities and equity of a company at a certain date. While the profit and loss calculation (report) shows the results that have been achieved by the company and the expenses incurred during a certain period, and the statement of changes in equity shows the sources and uses or reasons that cause changes in the company's equity.

From some of the definitions above, it can be concluded that financial statements are information that describes a company, the company's financial position and the results that have been achieved by the company, which will then become information that describes the company's performance which will later be able to provide assistance to users to make decisions.

\section{Liquidity}

Liquidity is a ratio used to measure the company's ability to meet short-term financial obligations in the form of short-term debts. According to Irham Fahmi (2012:121), the liquidity ratio is the ability of a company to meet its short-term obligations in a timely manner. Meanwhile, according to Kasmir (2012: 75), the liquidity ratio is a ratio that describes the company's ability to meet short-term obligations. In other words, the liquidity ratio serves to show or measure the company's ability to meet its obligations that are soon due. Hanafi and Abdul Halim (2009:75), reveal that liquidity is a ratio to measure the company's short-term liquidity ability by looking at the company's current assets relative to its current debt (debt in this case is the company's liability).

\section{Profitability}

Profitability ratio is a ratio to measure the level of effectiveness of the management (management) of the company which is indicated by the amount of profit generated from sales and investment. The point is that the use of this ratio shows the efficiency of the company. According to Sofyan Safri Harahap (2008:304) defines the profitability ratio, namely: "The profitability ratio is a ratio that describes the company's ability to earn profits through all existing capabilities and sources such as sales activities, cash, capital, number of employees, number of branches and so on".

\section{Solvency}

The solvency ratio is the ratio used to determine the company's ability to meet its shortterm and long-term obligations so that it is more comprehensive. According to Kasmir 


\section{Journal of Management and Leadership}

Vol.4 No.1, May 2021

(2012:151), the solvency ratio or Leverage Ratio is a ratio used to measure the extent to which the company's assets are financed by debt. This means how much debt burden is borne by the company compared to its assets. Meanwhile, according to Hanafi and Abdul Halim (2009:79), the solvency ratio is a ratio to measure the company's ability to meet its long-term obligations. According to Bambang Riyanto (2001:32), the solvency of a company shows the company's ability to fulfill all its financial obligations if the company is liquidated at that time.

\section{Share}

According to Martalena and Malinda (2011:12) in the journal Aviliankara and Sarumpaet (2017), is a proof of ownership of a company which includes the nominal value, company name, and followed by rights and obligations explained to each shareholder. Shares are a form of securities traded in the capital market. Shares are a sign of participation or ownership of a person or entity in a public company (Sunariyah: 2004).

\section{Signaling Theory}

Signaling theory according to Brigham and Houston (2011: 186) in the journal Novalia and Nindito (2017), is an action taken by the management of a company to provide instructions to investors on how management assesses the company's prospects. Signaling theory explains the company's reason for emphasizing the importance of information issued by the company on the investment decisions of parties outside the company.

While Signaling Theory according to (Suwardjono, 2005) in the journal Khairudin and Wandita (2016), are information signals needed by investors to consider and determine whether investors will invest their shares or not in the company concerned. Complete, relevant, accurate and timely information is needed by investors in the capital market as an analytical tool to make investment decisions. The information published will provide a signal for investors in making investment decisions. If the financial information has a good assessment, the information received by investors is good news so that investors are interested in trading shares and this leads to changes in stock prices. On the other hand, if the financial information shows a bad rating, the information received by investors is bad news and affects trading and stock prices as well.

Hanafi and Abdul Halim (2009:75), reveal that liquidity is a ratio to measure the company's short-term liquidity ability by looking at the company's current assets relative to its current debt (debt in this case is the company's liability). Research on liquidity was conducted by 


\section{Journal of Management and Leadership}

Vol.4 No.1, May 2021

Rahayu and Dana (2016), they examined the relationship between liquidity and stock prices. The study obtained the results that liquidity has a significant effect on stock prices. More specific research on liquidity was conducted by Widyanigrum and Suryono (2017). The research proves that liquidity has a significant effect on stock prices. Rianisari et al (2018)'s research also found similar results to Widyanigrum and Suryono (2017), that liquidity significantly affects stock prices. Based on the description above, the hypotheses that can be raised are:

H1 : Liquidity Ratio has an effect on Stock Price.

Profitability is the company's ability to generate profits by using the sources owned by the company, such as assets, capital or sales (Sudana, 2009: 25). Research on profitability was conducted by Widyanigrum and Suryono (2017). they examine the relationship between profitability and stock prices. The study obtained the results that profitability has a significant effect on stock prices. More specific research on profitability was conducted by Tiya et al (2018). The research proves that profitability has a significant effect on stock prices. From the results of research conducted by Octaviani and Komalasarai (2017), profitability has a significant effect on stock prices. This is consistent with research conducted by Tiya et al (2018) which in their research shows that profitability has a significant effect on stock prices. Based on the description above, the hypotheses that can be raised are:

H2: Profitability ratio has an effect on stock prices.

According to Kasmir (2012:151), the solvency ratio or Leverage Ratio is a ratio used to measure the extent to which the company's assets are financed by debt. This means how much debt is borne by the company compared to its assets. Meanwhile, according to Hanafi and Abdul Halim (2009:79), the solvency ratio is a ratio to measure the company's ability to meet its longterm obligations. There is also research on solvency conducted by Tiya et al (2018). they examine the relationship between solvency and stock prices. The study found that solvency had a significant effect on stock prices. Another study on profitability was conducted by Faleni and Herdianto (2019). This study proves that solvency has a significant effect on stock prices. From the results of research conducted by Susilawati (2012), solvency has a significant effect on stock prices. This is consistent with research conducted by Tiya et al (2018) which in their research shows that solvency has a significant effect on stock prices. Based on the description above, the hypotheses that can be raised are: 
Journal of Management and Leadership

Vol.4 No.1, May 2021

H3 : Solvency Ratio has an effect on Stock Price.

From the results of research conducted by Achmad Syaiful Susanto (2011) which in his research shows that there is an effect of liquidity (CR), profitability (ROA), solvency (DER), and firm size (total assets) simultaneously on stock prices. The ANOVA test showed a research significance of $<0.05(0.002<0.05)$, thus indicating the influence of liquidity (CR), profitability (ROA), solvency (DER), and firm size (total assets) simultaneously on stock prices. Based on the description above, the hypotheses that can be raised are:

H4 : Financial Ratio has an effect on Stock Price.

\section{Methodology}

This study is a research that focuses on financial ratios obtained through the annual financial statements of banking companies listed on the Indonesia Stock Exchange during the period 2015 - 2019. The type of research in this study is descriptive research using secondary data which is written data related to the object of research. issued by the company, the Indonesia Stock Exchange and from the Yahoo Finance website.

The research approach used in this study is a quantitative approach. The data from the analysis are then presented and discussed. The scope of the research object determined is in accordance with the problems to be studied, namely financial performance including liquidity, profitability, solvency and stock prices in banking companies listed on the Indonesia Stock Exchange for the 2015-2019 period.

In this study, the authors will take the population in the form of banking companies listed on the IDX for the 2015-2019 period. By using a purposive sampling technique with certain criteria in accordance with the research objectives as follows:

a. Banking Companies listed on the Indonesia Stock Exchange in the 2015-2019 period

b. Banking Company that publishes financial statements in 2015-2019 in full.

c. The Financial Statements used are Financial Statements that have been audited by a Public Accounting Firm, because they are deemed to have complied with the applicable accounting standards.

d. Financial statements that are used are income statements, reports of changes in capital, cash flow statements and company balance sheets. 
Journal of Management and Leadership

Vol.4 No.1, May 2021

Based on these criteria, from a total population of 45 banking companies, a sample of 38 companies was obtained with an observation period of 5 years, from 2015-2019, so that the number of samples of companies observed was 190 companies' financial statements.

\section{Data Testing Method}

In this study using descriptive statistical tests and classical assumption tests such as normality test, multicollinearity test, heteroscedasticity test and autocorrelation test. In addition, hypothesis testing was also carried out in the form of multiple linear regression analysis, model determination test, coefficient of determination test, $\mathrm{t}$ test and $\mathrm{f}$ test.

\section{Result}

Table 1

Descriptive Statistics Test Results

\begin{tabular}{|l|r|r|r|r|r|}
\hline \hline & N & Minimum & Maximum & Mean & Std. Deviation \\
\hline CR & 117 &, 07110 & 1,60087 &, 4941231 &, 41063863 \\
\hline ROA & 117 &,- 01056 &, 02559 &, 0076591 &, 00673744 \\
\hline DER & 117 &, 00728 & 12,67487 & 3,3131114 & 3,42555451 \\
\hline $\begin{array}{l}\text { HARGASAHA } \\
\text { M }\end{array}$ & 117 & 50 & 2800 & 598,84 & 565,412 \\
\hline $\begin{array}{l}\text { Valid N } \\
\text { (listwise) }\end{array}$ & 117 & & & & \\
\hline
\end{tabular}

Source: Secondary Data Processed, 2020

The dependent variable of stock prices has a minimum value of 50 obtained from PT Bank MNC Internasional, Tbk and a maximum value of 2800 obtained from PT Bank Mestika Dharma, Tbk. If you pay attention, the mean or average value of the stock price is 598.84 obtained from the standard deviation of 565,412.

The table above also shows that the Current Ratio (CR) variable shows a fairly large mean of 0.4941 or $49.41 \%$ above the debt ratio limit with a standard deviation of 0.4106 . The 


\section{Journal of Management and Leadership}

Vol.4 No.1, May 2021

minimum value of the Current Ratio (CR) is 0.0711 obtained from Bank OCBC NISP, while the maximum value of the Current Ratio is 1.6008 obtained from Panin Bank Syariah, Tbk.

Furthermore, it can be seen that the average value of the Return On Asset (ROA) variable is 0.0076 with a standard deviation of 0.0067 . This shows that the distribution of the Return On Assets variable data varies between one banking sector company and another banking sector company. The mean value is 0.0076 return on assets that the Return On Asset value is -0.01056 obtained from PT Bank Pembangunan Daerah Banten, Tbk, while the maximum value of Return On Assets is 0.02559 obtained from PT Bank Mestika Dharma, Tbk .

On the Debt to Equity Ratio variable in this study, the average value of the DER variable is 3.3131114 with a maximum value of 12.67487 obtained by PT Bank Pembangunan Daerah Banten, Tbk, and a minimum value of 0.00728 obtained from PT , Dubai Sharia Bank Tbk.

Table 2

Normality Test

\begin{tabular}{|c|c|c|c|}
\hline \multicolumn{4}{|c|}{ One-Sample Kolmogorov-Smirnov Test } \\
\hline & & & $\begin{array}{c}\text { Unstandardized } \\
\text { Residual }\end{array}$ \\
\hline \multicolumn{3}{|l|}{$\mathrm{N}$} & 117 \\
\hline \multirow[t]{2}{*}{ Normal Parameters ${ }^{a, b}$} & \multicolumn{2}{|l|}{ Mean } & ,0000000 \\
\hline & \multicolumn{2}{|l|}{ Std. Deviation } & 482,42084197 \\
\hline \multirow[t]{3}{*}{ Most Extreme Differences } & \multicolumn{2}{|l|}{ Absolute } & , 106 \\
\hline & \multicolumn{2}{|l|}{ Positive } & ,106 \\
\hline & \multicolumn{2}{|l|}{ Negative } &,- 091 \\
\hline \multicolumn{3}{|l|}{ Test Statistic } & , 106 \\
\hline \multirow[t]{3}{*}{ Monte Carlo Sig. (2-tailed) } & \multicolumn{2}{|l|}{ Sig. } &, $140^{\mathrm{d}}$ \\
\hline & \multirow[t]{2}{*}{$99 \%$ Confidence Interval } & Lower Bound &, 131 \\
\hline & & Upper Bound &, 149 \\
\hline \multicolumn{4}{|l|}{ a. Test distribution is Normal. } \\
\hline \multicolumn{4}{|l|}{ b. Calculated from data. } \\
\hline \multicolumn{4}{|c|}{ c. Lilliefors Significance Correction. } \\
\hline \multicolumn{4}{|c|}{ d. Based on 10000 sampled tables with starting seed 1314643744 . } \\
\hline
\end{tabular}

The probability value of monte carlo sig. (2-tailed) in table 4.3 which is the result of the Kolmogorov-Smirnov test shows a result of 0.135 . This value is above the significant value of 0.05 . Thus, it can be said that the residual value of the data is normally distributed and has met the assumption of normality. 
Table 3

\section{Multicollinearity Test Results}

\begin{tabular}{ll|l|l}
\multicolumn{2}{c}{$\begin{array}{c}\text { Coefficients } \\
\text { Model } \\
\text { Collinearity } \\
\text { Tolerance }\end{array}$} & $\begin{array}{c}\text { Statistics } \\
\text { VIF }\end{array}$ \\
\hline 1 & & & \\
\hline & (Constant) &, 959 & 1,043 \\
\hline & CR &, 960 & 1,042 \\
\hline & ROA &, 927 & 1,079 \\
\hline
\end{tabular}

a. Dependent Variable: HARGASAHAM

Based on the table above, it can be seen that the variables in this study are not correlated with each other. This can be seen from the tolerance value of all variables whose value is greater than 0.10, namely the Current Ratio (CR) variable of 0.959; Return on Asset (ROA) variable is 0,960; and the variable Debt to Equity (DER) of 0.927. Along with a tolerance value greater than 0.10, the Variance Inflation Factor (VIF) value in this study is also less than 10 for each variable, namely the Current Ratio (CR) variable of 1.043; Return On Asset (ROA) variable is 1.042; and the Debt to Equity (DER) variable is 1.079. Thus, it can be concluded that there is no multicollinearity problem in this study.

\section{Table 4}

\section{Heteroscedasticity Test Results}

\begin{tabular}{|c|c|c|c|c|c|c|}
\hline \multicolumn{7}{|c|}{ Coefficients $^{\mathrm{a}}$} \\
\hline \multirow[b]{2}{*}{ Mode } & & \multicolumn{2}{|c|}{ Unstandardized Coefficients } & \multirow{2}{*}{$\begin{array}{c}\text { Standardized } \\
\text { Coefficients } \\
\text { Beta } \\
\end{array}$} & \multirow[b]{2}{*}{$t$} & \multirow[b]{2}{*}{ Sig. } \\
\hline & & $\mathrm{B}$ & Std. Error & & & \\
\hline \multirow[t]{4}{*}{1} & (Constant) & 143,315 & 63,680 & & 2,251 &, 026 \\
\hline & CR & 198,619 & 71,312 &, 251 & 2,785 &, 006 \\
\hline & ROA & 11226,883 & 4343,507 &, 233 & 2,585 &, 011 \\
\hline & DER & 8,469 & 8,693 & ,089 & 974 &, 332 \\
\hline
\end{tabular}

a. Dependent Variable: hargashm

In the table above, it can be seen that the significance value of all variables to the absolute residual is above 0.05; namely the variable Current Ratio (CR) of 0.006; variable Return 


\section{Journal of Management and Leadership}

Vol.4 No.1, May 2021

On Assets (ROA) of 0.011; and the variable Debt to Equity Ratio (DER) of 0.332. It can be seen that the significance value of the variable Current Ratio (CR) and Return On Assets (ROA) to the residual is below 0.05 , namely the variable (CR) of 0.006 and variable (ROA) of 0.011 while the variable (DER) is above 0.05 of 0.332 . This indicates that the data in this study do not have the same variance or homoscedasticity according to the scatterplot analysis carried out. Thus, based on the results of the two tests above, it can be concluded that in this study there was heteroscedasticity due to sig $<0.05$.

\section{Table 5}

Multiple Linear Regression Test Results

\begin{tabular}{|c|c|c|c|c|c|c|}
\hline \multicolumn{7}{|c|}{ Coefficients $^{\mathrm{a}}$} \\
\hline \multirow{2}{*}{\multicolumn{2}{|c|}{ Model }} & \multicolumn{2}{|c|}{ Unstandardized Coefficients } & \multirow{2}{*}{$\begin{array}{c}\text { Standardized } \\
\text { Coefficients } \\
\text { Beta } \\
\end{array}$} & \multirow[b]{2}{*}{$t$} & \multirow[b]{2}{*}{ Sig. } \\
\hline & & $B$ & Std. Error & & & \\
\hline \multirow[t]{4}{*}{1} & (Constant) & 100,034 & 100,790 & & 992 &, 323 \\
\hline & $C R$ & 246,052 & 112,872 & ,179 & 2,180 & 031 \\
\hline & ROA & 42549,768 & 6874,798 &, 507 & 6,189 &, 000 \\
\hline & DER & 15,493 & 13,759 & ,094 & 1,126 & 263 \\
\hline
\end{tabular}

a. Dependent Variable: HARGASAHAM

Based on the output above, the model regression equation can be made as follows:

Share Price: $100.034+246.052 \mathrm{CR}+42549,768 \mathrm{ROA}+15,493+\mathrm{e}$

The regression transformation equation above has the following meaning:

1. The constant coefficient of 100.034 which indicates the stock price is worth 100.034 if each variable CR, ROA and DER is worth 0. A positive constant coefficient value indicates that financial performance tends to increase.

2. The regression coefficient $\mathrm{X} 1$ or the $\mathrm{CR}$ variable is 246.052 , this shows that if every $1 \%$ increase in the CR variable, while the ROA and DER variables are assumed to be constant, the share price will decrease by 246.052 
3. The $\mathrm{X} 2$ regression coefficient or ROA variable is 42549,768 , this shows that for every $1 \%$ increase in the ROA variable, while the CR and DER variables are assumed to be constant, the share price will experience a decrease of 42549,768.

4. The regression variable $\mathrm{X} 3$ or the DER variable is 15,493 . This shows that if every $1 \%$ increase in the DER variable while the CR and ROA variables are assumed to be constant, then the share price will increase by 15,493.

Table 6

\section{Partial Parameter Significant Test (t Significant Test)}

\begin{tabular}{|c|c|c|c|c|c|c|}
\hline \multicolumn{7}{|c|}{ Coefficients $^{a}$} \\
\hline & & \multicolumn{2}{|c|}{ Unstandardized Coefficients } & \multirow{2}{*}{$\begin{array}{c}\text { Standardized } \\
\text { Coefficients } \\
\text { Beta } \\
\end{array}$} & \multirow[b]{2}{*}{$\mathrm{t}$} & \multirow[b]{2}{*}{ Sig. } \\
\hline \multicolumn{2}{|c|}{ Model } & $\mathrm{B}$ & Std. Error & & & \\
\hline \multirow[t]{4}{*}{1} & (Constant) & 100,034 & 100,790 & & ,992 &, 323 \\
\hline & $\mathrm{CR}$ & 246,052 & 112,872 &, 179 & 2,180 &, 031 \\
\hline & ROA & 42549,768 & 6874,798 &, 507 & 6,189 &, 000 \\
\hline & DER & 15,493 & 13,759 &, 094 & 1,126 &, 263 \\
\hline
\end{tabular}

a. Dependent Variable: HARGASAHAM

\section{H1: Liquidity Ratio Affects Stock Prices.}

Looking at the table above, the regression results on the liquidity variable on stock prices produce a t-count value of $2.180>$ t-table 1.981 with a significant value (sig.) of $0.03<0.05$. It can be concluded that $\mathrm{H} 1$ is accepted which means that there is an influence between the Liquidity variable on the Stock Price.

\section{H2: Profitability has an effect on stock prices.}

Looking at the table above, the results of the regression on the Profitability variable on the Stock Price yield a t-count value of $6.189>$ t-table 1.981 with a significant value (sig.) of $0.00<0.05$. It can be concluded that $\mathrm{H} 2$ is accepted, which means that there is an influence between the profitability variables on the stock price.

\section{H3: Solvency Affects Stock Prices.}

Looking at the table above, the results of the regression on the Solvency variable on the Stock Price yield a t-count value of $1.126<$ t-table 1.984 with a significant value (sig.) of $0.26>$ 
0.05. It can be concluded that $\mathrm{H} 3$ is rejected, which means that there is no influence between the solvency variables on the stock price.

Table 7

Simultaneous Significance Test (F Statistics Test)

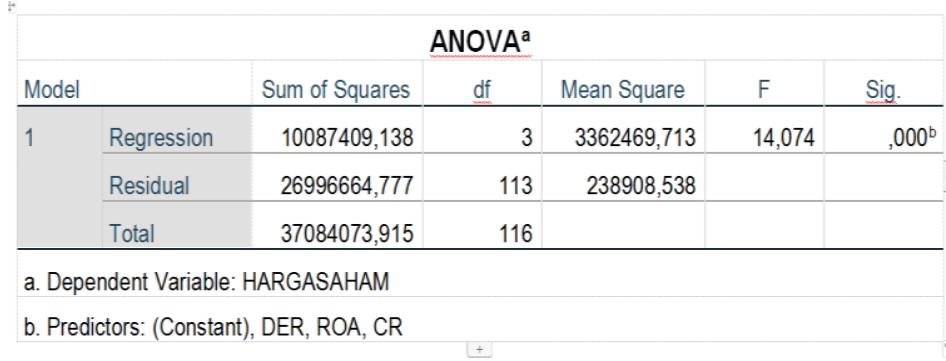

\section{H4: Liquidity, Profitability, and Solvency have a significant effect on stock prices.}

The fourth hypothesis examines the influence of Liquidity, Profitability, and Solvency have a significant effect on stock prices. Looking at table 4.10, the regression results can be seen that together (simultaneously) the independent variables have a significant influence on the dependent variable, this is evidenced by the calculated $\mathrm{F}$ value of $14.07>\mathrm{F}$ Table 2.68 with a significant value (sig.) of $0.000<0.05$. then the regression model can be used to predict stock prices or it can be said that CR, ROA, and DER together have a significant effect on stock prices. Thus $\mathrm{H} 4$ is accepted in this study.

\section{Conclusion and Recommendation}

\section{Effect of Liquidity Ratio on Stock Prices.}

Based on the results of the $t$ test for the liquidity variable projected by the Current Ratio (CR) has a significance of 0.031 , which means it is smaller than 0.05 , then $\mathrm{H} 1$ is accepted. Thus it can be concluded that liquidity has a significant effect on stock prices. The liquidity ratio shows the extent to which current assets cover current liabilities.

If the company is believed to be able to pay off its short-term obligations, the company is in good condition and can increase stock prices because investors are interested in the company's financial condition like this.

Thus, if the company's liquidity capacity is good, investors do not need to worry about whether the capital they have invested in the company will return and provide benefits for them 
Journal of Management and Leadership

Vol.4 No.1, May 2021

or not. Because if a company whose liquidity level is not good, it has a tendency to be shunned by investors for fear that the funds they invest will not return and result in losses for investors. This is consistent with research conducted by Rahayu and Dana (2016) and Tiya et al (2018) which in their research shows that CR (Liquidity) has a significant effect on stock prices.

\section{The Effect of Profitability Ratios on Stock Prices}

Based on the results of the t test for the profitability variable projected by Return On Assets (ROA) has a significance of 0.000 , which means it is smaller than 0.05 , then $\mathrm{H} 2$ is accepted. Thus it can be concluded that profitability has a significant effect on stock prices. ROA (Return On Assets) shows the company's ability to generate profits from the assets used.

ROA is obtained from the ratio between earnings after taxes and total assets. Thus, the higher the ROA of a company, the higher the value of the company's assets and cause the stock price to be higher because it is in great demand by investors. this can be because if the company can achieve good profits or profits in each period, investors do not need to worry about the company losing money or even going bankrupt. Thus, the profits or profits obtained by the company can also be enjoyed by investors and open up the possibility of new investors who want to invest their capital there which can increase the market price of the company's shares. This is consistent with research conducted by Octaviani and Komalasarai (2017) and Widyaningrum and Suryono (2017) which in their research shows that ROA (Profitability) has a significant effect on stock prices.

\section{The Influence of Solvency Ratios on Stock Prices}

Based on the results of the $t$ test for the Solvency variable projected by Debt to Equity (DER) has a significance of 0.263 , which means that it is greater than 0.05 , then $\mathrm{H} 3$ is rejected. Thus it can be concluded that solvency has no significant effect on stock prices. Solvency ratio is a ratio to assess the company's ability to pay all its obligations, both short term and long term if the company is dissolved. The higher the solvency, the company must increase its profits as much as possible in order to be able to finance and pay debts. This is not in line with research conducted by Tiya et al (2018) and Sandra et al (2016) which in their research shows that DER (Solvency) has a significant effect on stock prices.

\section{The Effect of Liquidity, Profitability and Solvency Financial Ratios on Stock Prices}


The results of the F test show that the calculated F result is 14.07 with a significance level of 0.000 . Because the significance level is smaller than 0.05, it can be concluded that the variables of liquidity, profitability and solvency simultaneously or jointly have a significant

effect on the dependent variable, namely stock prices. Stock prices also reflect the value of a company. If the company achieves good performance, then the company's shares will be in great demand by investors. Good achievements achieved by the company can be seen in the financial statements published by the company (issuer).

To assess the financial condition and performance of the company, financial analysis requires several benchmarks. The benchmark that is often used is financial ratios. Thus, companies that have good liquidity, profitability and solvency ratios tend to have good stock price levels and this is used as a reference or benchmark for investors to invest in these companies. Because no one investor wants to lose in every investment they make.

This is consistent with research conducted by Octaviani and Komalasarai (2017) which in their research shows that there is an effect of liquidity (CR), profitability (ROA) and solvency (DER) simultaneously on stock prices. The same results were also obtained from research conducted by Rahayu and Dana (2016) which showed that the ratio of liquidity, profitability and solvency had an effect on stock prices.

\section{References}

Adipalguna dan Suarjaya , 2016. Pengaruh Likuiditas, Solvabilitas, Aktivitas Dan Profitabilitas Terhadap Harga Saham. E-Jurnal Manajemen, Universitas Udayana.

Akhmadi Dan Prasetyo, 2018. Profitabilitas, Rasio Solvabilitas Dan Harga Saham; Studi Empirik Pada Perusahaan Subsektor Batubara Yang Terdaftar Di Bursa Efek Indonesia Periode 2010-2014. Jurnal Riset Akuntansi Terpadu, Vol.11, No.1, Universitas Sultan Ageng Tiratayasa

Alfianti Dan Andarini, 2017. Pengaruh Profitabilitas Terhadap Harga Saham Pada Perusahaan Makanan Dan Minuman Yang Terdaftar Di Bursa Efek Indonesia. Jurnal Bisnis Indonesia, UPNV Jawa Timur. 


\section{Journal of Management and Leadership}

Vol.4 No.1, May 2021

Anwar, 2019. Dasar Dasar Manajemen Keuangan. Edisi Pertama. Jakarta : Kencana Fahmi, Irham, 2013. Analisis Laporan Keuangan. Edisi Ketiga. Bandung: Alfabeta.

Aryani dan Zulkifli, 2016. Pengaruh Rasio Profitabilitas Terhadap Harga Saham Pada

Perusahaan Industri Logam Dan Sejenisnya Yang Terdaftar Di Bursa Efek Indonesia Tahun 2007-2011. Jurnal Akuntansi Politeknik Sekayu (ACSY). Politeknik Negeri Sriwijaya.

Aviliankara Dan Sarumpaet, 2017. Pengaruh Rasio Likuiditas, Rasio Solvabilitas, Rasio Aktivitas, Dan Rasio Profitabilitas Terhadap Harga Saham (Studi Empiris Pada Perusahaan Manufaktur Sektor Barang Konsumsi Yang Terdaftar Di Bursa Efek Indonesia Periode 20132015). Universitas Widyatama, ISSN- 2252-3936

Brigham, Eugene F. dan Joel F. Houston, 2013. Dasar-Dasar Manajemen Keuangan. Edisi 11 Buku 2. Jakarta: Salemba Empat

David dan Kurniawan Indonanjaya. 2010. Manajemen Investasi: Pendekatan Teknikal dan Fundamental untuk Analisis Saham. Edisi Pertama. Yogyakarta: Graha Ilmu

Erwanda dan Ruzikna,2017. Pengaruh Rasio Profitabilitas Terhadap Harga Saham Pada Perusahaan Konstruksi Yang Terdaftar Di Bursa Efek Indonesia Tahun 2010-2014, Jom Fisip. Universitas Riau

Faleni Dan Herdianto, 2019. Pengaruh Profitabilitas Dan Solvabilitas Terhadap Harga Saham (Studi Pada Perusahaan Kontruksi Bangunan Yang Tercatat Di Bursa Efek Indonesia Periode 2013-2017). Business Journal, Volume 05, No. 02, April 2019, P. 45-56, E-ISSN: 2620-3634, P-ISSN: 2407-6392, Telkom University

Fitrianingsih Dan Budiansyah, 2018. Pengaruh Current Rasio Dan Debt to Equity Ratio Terhadap Harga Saham Di Perusahaan Food And Beverage Yang Terdaftar Di Bursa Efek Indonesia Periode 2013 - 2017, Jurnal Riset Akuntansi Terpadu Vol.12 No.1, 2018 Hal. 144166, Sekolah Tinggi Ilmu Ekonomi Banten

Halimatussakdiah, 2018. Pengaruh Profitabilitas, Likuiditas Dan Deviden Per Share Terhadap Harga Saham Pada Perusahaan Lq-45 Yang Terdaftar Di Bursa Efek Indonesia. Jurnal Valuta, Universitas Islam Riau. Vol 4. No 1 ISSN : 2502-1419

Hikmah, 2018. Pengaruh Rasio Profitabilitas Terhadap Harga Saham Perusahaan Sub Sektor Minyak Dan Gas Bumi Yang Terdaftar Di Bei . Journal Of Management And Business, Universitas Putera Batam. 


\section{Journal of Management and Leadership}

Vol.4 No.1, May 2021

Kasmir. Analisis Laporan Keuangan. Edisi Kesebelas. Jakarta : PT Raja Grafindo Persada

Khairudin dan Wandita, 2017. Analisis Pengaruh Rasio Profitabilitas, Debt To Equity Ratio (DER) Dan Price To Book Value (PBV) Terhadap Harga Saham Perusahaan Pertambangan Di Indonesia. Jurnal Akuntansi Dan Keuangan, Volume 8, No. 1, ISSN: 2087-2054, Universitas Bandar Lampung

Machfiroh Et Al, 2020. Analisis Pengaruh Likuiditas, Solvabilitas Dan Profitabilitas Terhadap Harga Saham Pada Perusahaan Sektor Pertanian Yang Terdaftar Di Bursa Efek Indonesia (BEI). Jurnal Ilmiah Akuntansi, Politeknik Negeri Tanah Laut. Vol. 4 No. 1 E-ISSN: 26855607

Mardian dan Sanusi , 2017. Pengaruh Likuiditas Terhadap Harga Saham Dengan Profitabilitas Sebagai Variabel Intervening Pada Perusahaan Manufaktur Sektor Aneka Industri Yang Terdaftar Di Bei Periode 2013-2016. Tirtayasa Ekonomika, Universitas Sultan Ageng Tirtayasa

Novalia dan Nindito, 2016. Pengaruh Konservatisme Akuntansi Dan Economic Value Added Terhadap Penilaian Ekuitas Perusahaan. Jurnal Ilmiah Wahana Akuntansi, Universitas Negeri Jakarta

Nurlia , 2016. Pengaruh Rasio Profitabilitas Terhadap Harga Saham Pada Perusahaan Rokok Yang Terdaftar Di Bursa Efek Indonesia. Jurnal Sains Terapan, Universitas Balikpapan

Octaviani dan Komalasarai, 2017. Pengaruh Likuiditas, Profitabilitas, Dan Solvabilitas Terhadap Harga Saham . Jurnal Akuntansi, Universitas Serang Raya.

Rahayu Dan Dana, 2016. Pengaruh Eva, Mva Dan Likuiditas Terhadap Harga Saham Pada Perusahaan Food And Beverages. E-Jurnal Manajemen Unud, Universitas Udayana, Vol. 5, No.1, 2016: 443 - 469 ISSN: 2302-8912

Ramadhani, 2017. Pengaruh Debt to Equity Ratio (Der), Return On Equity (Roe), Dan Net Profit Margin (Npm) Terhadap Harga Saham Perusahaan Sektor Pertambangan Yang Terdaftar Di Bursa Efek Indonesia Periode 2011-2015. Jurnal Profita Edisi 8, Universitas Negeri Yogyakarta

Ramdhani, 2013. Pengaruh Return On Asset s Dan Debt to Equity Ratio Terhadap Harga Saham Pada Institusi Finansial Di Bursa Efek Indonesia, Journal The WINNERS , Binus University, Vol. 14 No. 1 


\section{Journal of Management and Leadership}

Vol.4 No.1, May 2021

Rianisari Et Al ,2018. Pengaruh Likuiditas, Leverage, Dan Profitabilitas Terhadap Harga Saham Industri Makanan Dan Minuman Di BEI. Jurnal Ilmu Manajemen, Universitas Tadulako. Vol 4, No 2, ISSN : 2443-3578

Sandra Et Al, 2016. Pengaruh Rasio Solvabilitas Dan Profitabilitas Terhadap Harga Sahampada Perusahaan Sektor Pertambangan. E-Journal Bisma, Universitas Pendidikan Ganesha. Volume 4

Susanto, Achmad Syaiful, 2011. Pengaruh Likuiditas, Profitabilitas, Solvabilitas dan Ukuran Perusahaan Terhadap Harga Saham Perusahaan Farmasi Di BEI. Jurnal Universitas Negeri Surabaya, Surabaya.

Susilawati, 2012. Analisis Perbandingan Pengaruh Likuiditas, Solvabilitas Dan Profitabilitas Terhadap Harga Saham Pada Perusahaan LQ 45. Jurnal Akuntansi ISSN: 2085-8698 Volume 4, Nomor 2, Universitas Kristen Maranatha

Tandelilin, E, 2010. Portofolio dan Investasi Teori dan Aplikasi. Edisi Pertama. Yogyakarta: Kanisius.

Tiya Et Al, 2018. Pengaruh Likuiditas, Solvabilitas Dan Profitabilitas Terhadap Harga Saham Pada Perusahaan Yang Terdaftar Dalam Indeks Lq 45. Jurnal Manajemen Dan Keuangan, Sekolah Tinggi Ilmu Ekonomi Sultan Agung, ISSN : 2338-4328 Vol. 6, No. 2

Widyaningrum Dan Suryono, 2017. Pengaruh Likuiditas, Profitabilitas Dan Total Perputaran

Aset Terhadap Harga Saham. Jurnal Ilmu Dan Riset Akuntansi, Sekolah Tinggi Ilmu Ekonomi Indonesia (STIESIA) Surabaya, Volume 6, Nomor 10 E-ISSN : 2460-0585

www. finane.yahoo.com

www.idx.co.id

https://www.youtube.com/watch?v=7OYkRGcAK1odant=1148s/ Uji t dan Uji F dalam Analisis Regresi Berganda dengan SPSS Lengkap

https://www.youtube.com/watch?v=i-gSU41wopl/ Analisis Deskriptif Menggunakan SPSS |Tutorial SPSS

Terbaru

https://www.youtube.com/watch?v=Q1/rsLDm9codant=621s/ Uji Normalitas Kolmogorov Smirnov dengan SPSS Full Edisi 


\section{Journal of Management and Leadership}

Vol.4 No.1, May 2021

https://www.youtube.com/watch?v=UnB7CWN_xmEdant=657s/ Cara Uji Multikolinearitas Tolerance dan VIF dengan SPSS

https://www.youtube.com/watch?v=uQ-wp4xfoQs/ Sukses Uji Heteroskedastisitas Metode Glejser dengan SPSS UPDATE

https://www.ibm.com/support/pages/ibm-spss-statistics-26-documentation

https://www.spss-tutorials.com/basics/

http://www.sussex.ac.uk/its/pdfs/SPSS_Exact_Tests_21.pdf 